\title{
The Crucial Role of Orientation Programs on Retention of New Employees in Commercial Banks in Keya
}

\author{
Dr. Catherine N. Wainaina \\ Senior Lecturer at Kiriri Womens University of Science and Technology (Kwust) \\ Kenya
}

\begin{abstract}
Employees typically have unrealistically inflated expectations about the organizations they consider joining. However after inception in the new employment, the initial expectations are disconfirmed and usually this leads to dissatisfaction. They regret and start resisting and eventually leave. It is argued that employees who get Realistic Job play view (RJP) during the selection process have higher job satisfaction and more realistic expectations. They are likely to be retained in the job for a longer time as compared to those who do not get adequate orientation. A study done in 2016 in 224 employees working in Pakistan in telecommunication and Banking sectors showed a significant positive relationship between realistic information and job satisfaction. This study therefore sought to identify different human resource interventions that would positively influence now employees, by preparing them psychologically to adapt to the new job and possibly have influence on their job acceptance, influence their retention rates and influence their post-employment job satisfaction and consequently lower resistance. Employee resistance is seen as the greatest set back to employee retention and a great impediment to organization expansion and growth due to its negative repercussions.
\end{abstract}

Keywords: Realistic job preview (RJP) Employee Resistance, Employee Retention.

\section{INTRODUCTION}

Realistic job preview (RJP) and Realistic Orientation programs for new Employees (ROPES) are Human Resources Sinterventions that have been designed to reduce turnover rates among new employees. According to Pitt, (2013) they are seen as a medical vaccination which injects new employees to make them know and become immune to the reality of the new job. The aim of orientation programs is reduce employee`s anxiety and improve their job expectation especially their attitude towards the new job and the entire organization.

According to (Mustafa 2010), orientation also enhances credibility of the organization and as a result it may reduce employee turnover. RJP as a Human resource intervention are supposed to:-

a) Reduce voluntary employee turnover according to (Tomprou 2011)

b) It saves time for the organization in acquiring a "strategic fit for new employees (Pitt 2013)

c) It prevents inappropriate hiring costs since the newly recruited employees can decide to take or leave the job at orientation stage. (Breaugh 2007).

Organizations use different types of orientation programs depending on their suitability on the type of the new job (champ noise 2004) The orientation programs should balance between the negative and positive information about the job (Champanose 2004) the orientation programs include, verbal presentations in form of lecturers, video tapes, films, life demonstrations about the job, job roles among others.

In U.S.A new recruits to military school are exposed to RSP through a combination of orientation programs like films, real video shows, life lectures. This is to assist them to internalize the reality of military operators. (Rosemond 2012). This makes them psychologically prepared for the task ahead. It also helps them to face the reality and decide on whether to join or quit at induction stage to avoid of the cost of training. Attitude it is a learned internal predisposition towards some types of object or stimulus according to Judge (2009) 
Attitude has three components. The effective component that refers to employees evaluation of "liking" or an emotional response to stimulus.

Cognition refers to knowledge or belief that one has about something and behavioral intention that refers to a person's willingness to take action with regard to stimulus (yukl, 1998). Attitude fulfills certain basic functions in orientation training program (1) knowledge (2) adjustment (3) ego defense (4) value expression (Katou, 2008). Therefore orientation programs are supposed, to address to the new employees attitude about a job and the organization in general in addition to other issues like the management structures and locations.

\section{The OBJeCtives OF THIS STUdY IS To}

a) Establish the influence of orientation attitude training on employee retention

b) Evaluate the influence of orientation life lectures on employee retention

c) To examine the influence of orientation audiovisual reality exposure on employee retention.

Orientation programs may reduce employee turnover if they are administered well depending on the requirements of each recruit. The different RJP methods should aim at lowering expectations of new employees to the job (Storey, 2012). However the induction program should be planned according to the job perspective of each individual or according to the type of job (Ndungu 2011). RJP is supposed to change the behavior of new employees by changing their attitude towards the job and making them more prepared for any eventuality in the new work place (Earnest, 2011). According to Wanaous (1996) orientation programs Reduce Stress levels for New Employees (ROPES) that can only be deflated through attitude training which can be achieved through ROPES.

\section{Conceptual Framework}

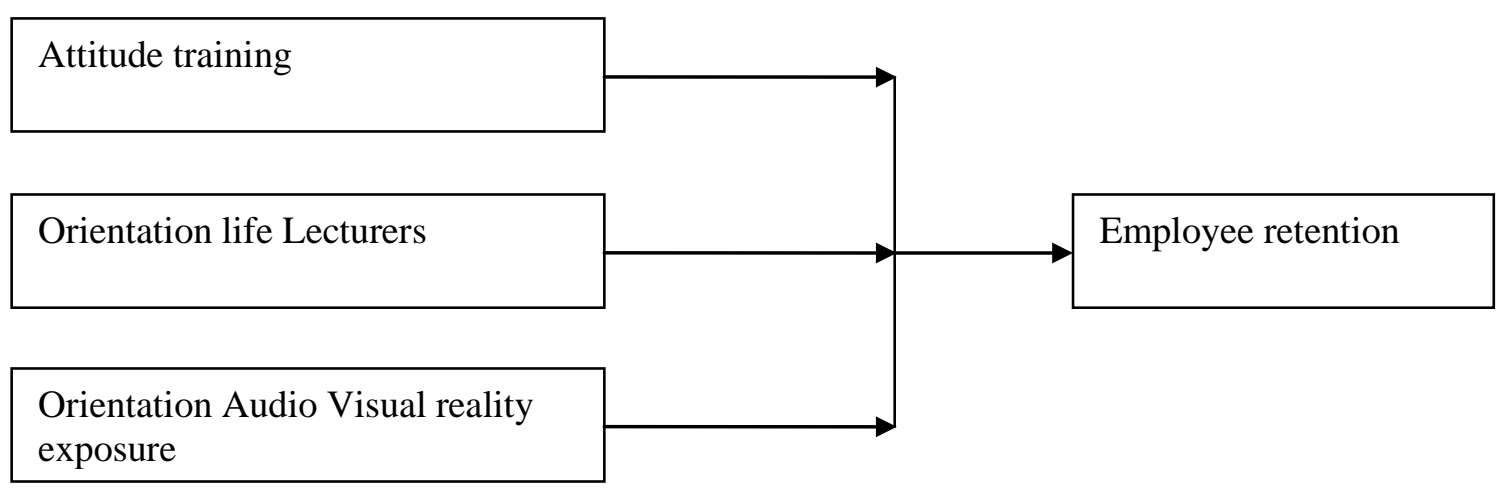

\section{RESEARCH METHODOLOGY}

The study adopted a descriptive survey research design using both quantitative and qualitative approaches stratified random sampling was used to sample 43 banks and using Cochrane (1963) equation and 385 respondents where sampled.

Data correction was done using questionnaire. A five dimension likert scale was used:-Descriptive analysis was used to analyze the socio-demographic profile of the respondents and further analyzed using corrections to analyze the relationships between pre-hiring expectations and post hiring experience of an employee.

\section{RESEARCH FINDINGS AND DISCUSSIONS}

A majority $68.3 \%$ respondents agreed with the fact that banks needed to put in place orientation programs as precursor programs that assess new employees to adapt to their new job. $65 \%$ agreed that employee orientation training, increased employee retention since the new employees were well equipped with prior knowledge of what to expect in the actual job.

Correlation analysis was significant since attitude training was $r=.696, p<0.001$ with retention strategy. Life lectures had a positive relationship with retention at $(r=.650 \mathrm{p}<0.001)$ at 0.01 significance level. Audio visual reality exposure at ( $\mathrm{r}=.628 \mathrm{p}>0.001)$ significance level.

The coefficient analyses indicated that attitude training had the highest predictive power on retention at 0.413 , followed by audio visual reality exposure at 0.380 , while life lectures were third at 0.258 . 
Therefore all the attitude training and audio visual exposure were significant predictors of retention, however life lectures was a weak but significant predictor of retention.

\section{Findings OF THE STUdY}

The findings established that there was dire need for a well planned induction program to give new recruit realistic job pre-view induction will assist new employees not only to be psychologically prepared for any eventuality but also help in changing their initial attitude on the new job they become more positive about the job and the entire organization and hence they are more likely to be retained in the job. Further findings establish their induction attitude training would reduce employee frustration since is assist them to anticipate any changes and challenges they might encounter in their task performance and hence help them to be more adaptive.

Therefore, the study would recommend for, a well establishment and well planned induction programs for new employees that may assist financial institutions and especially banks to remain relevant and competitive. Nurturing the unique Human Resource Knowledge capital may be attained through well planned orientation program. Such unique human resource skills and competences are crucial to the banks competitive needs. The ultimate goal of retaining such skills is to assist financial institution to cope and realize the escalating global banking standards.

The study therefore recommend that the management of commercial banks should have a well spelt policy on induction training programs and guidelines on the methods to be used in induction training for each category of employees to make induction more relevant and positively influence the new employees psychology and attitude towards their new jobs.

Orientation program trainers should also be conversant with the needs of new employees and the relevant methods of the training, to make orientation training relevant according to the trainees needs, to have a "fit" between orientation training and retention and to match the needs and the aspired goals of the banking institutions.

\section{REFERENCES}

[1] Baker, H.G. (1985). The Unwritten Contract Job Perceptions Personnel Journal 6(7:37-41)

[2] Breaugh. A. (2007) .Realistic Job Preview. A Critical Appraisal and Future Research Directions: The Academy Of Management Review. Oct 8 (4) 612-619

[3] Judge W. \& Douglas T. (2009). Organizational Change Capacity: The Systematic Development of a Scale. Journal of Organizational Change Management 22(6) 635 -649.

[4] Mustafa S. (2010). Impact of Realistic Job Messages on Competition Edge In The Long Run University Of Kelaniyu, Sri Lanka, ICBI 2010 http://www.aupc.info/wp-content/upload2014/08 v71-6 pg.

[5] Ndungu N. (2011). The Role of Central Bank of Kenya in Kenyan Economic Transformation. Business Management Review Journal No.5 Government Printers.

[6] Pitt L.F. \& Ramasesh B (1995). Realistic Job Information and Sales Job Turnover. And investigative Study journal of managerial psychology 10. (5), 29.

[7] Pitt, B.L, \& Runasesh, B. (2013). Realistic Job Information and Sales Force Turnover: An Investigative journal Managerial Psychology 10(5), 29-36 MCB University Press.

[8] Premack, S.L And J.P Wanaous (1985). "A Meta-Analysis of Realistic Job Preview Experiements "Journal of Applied Psycology -70 (4):706-719.

[9] Rosemond B. \& Samoah A. (2012). Resistance to Organization Change A Case Study Of Oti Yeboah Complex Limited International Business And Management Journal Vol No.1,2012 Pp 135-145

[10] Storey J. (2012).Human Resource Management: A Critical Text $\left(4^{\text {th }}\right.$ Ed) London Thomson.

[11] Tomprou, M. \& Nikolaou, I. (2011) A Model of Psychological Contract Creation Upon Organization Career Development International , 16(4),342-363

[12] Wanaous J.P. (1992). Orgnaizationa Entry: Recruit Selection and Socialization of New Comers $2^{\text {nd }}$ Ed. Reading M.A Addison Wesley Publishing Company. 
[13] Wanous J.P, Poland, J.D, Premack S.L \& Davis K.S. (1992). The Effects of Met Expectations on Attitudes \& Behaviours A Review of Meta-Analysis. Journal of Applied Psychology 77(3) 2011. Http://dx.dol.Org//101037/00219010

[14] Yukl G. (1998). Leadership, In Organizations Englewood, Cliffs NJ: Prentice Hell Inc.

\section{AUTHOR'S BIOGRAPHY}

Dr. Catherine Wainaina, Phd holder in Business Studies (HRM), from Jomo Kenyatta University of Agriculture and Technology (JKUAT). i have been a lecturer in Business studies in various public Universities in Kenya and currently I am a senior lecturer in Kiriri womens University of Science and Technology (KWUST) in kenya. 